\title{
KNOWLEDGE REGARDING PREVENTION OF OBESITY AMONG STUDENTS STUDYING IN SELECTED SENIOR SECONDARY SCHOOL OF JAIPUR, RAJASTHAN
}

\author{
Mr. Shashikant Sharma
}

(PHD Scholar, Mahatma Gandhi University of Medical Sciences \& Technology, Jaipur) Asst. Registrar, Rajasthan University of Health Sciences, Jaipur

Corresponding email: shashikant.sharma85@gmail.com

\begin{abstract}
Introduction: "The real solution to childhood obesity lies in changing our built environment. There is no other way to approach it." (Dr.Goutham Rav) "Food is the most abused anxiety drug .exercise is the most underutilized antidepressant"

Material \& Methods: The study was conducted in the selected senior secondary schools of Jaipur, Rajasthan. Two hundred forty students who met the inclusion criteria were selected as the sample for the present study. Purposive sampling technique was used to select the samples for the study.
\end{abstract}

Result: The findings of the present study reveals that highest percentage $(90 \%)$ of students had average knowledge attitude practice regarding habits in prevention of obesity and others comes under poor (3.33\%) and remaining students having good knowledge (6.67\%) about habits in prevention of obesity.

Conclusion: Students in poor knowledge category were $3.33 \%$. Students having average knowledge were 90\%. Students having good knowledge were 6.67\%. Students having excellent knowledge were $0 \%$.

Keyword: Knowledge, Obesity

INTRODUCTION: Adolescence (10 to $19 \mathrm{yr})$ is a period of heightened concern regarding obesity. Worldwide more than 1.2 billion are adolescent and about $21 \%$ ( about 243million) of Indian population are adolescent. The incidence of obesity increases during this age period and tends to persist into adulthood .The WHO describes obesity as one of today's most important 'public health problem 'and has designated obesity as a 'global epidemic 'and also one of the today's most neglected public health problems. Obesity is a consequence of an energy imbalance - i.e., when energy intake exceeds energy expenditure over an extended period of time. Obesity is now reaching epidemic proportions in both developed and developing countries and is affecting not only adults but also children and adolescents .It is a key risk factor for many chronic and non communicable diseases.

Obesity is defined as excess of body fat. The abnormal growth of adipose tissue 
may be due to an enlargement of fat cell size (hypertrophic obesity) or an increase in fat cell number (hyper plastic obesity) or both [1]

Body Mass Index (BMI) is an index of weight-for-height that is commonly used to classify underweight, overweight and obesity. It is determined by the weight in kilograms divided by the square of the height in meters $(\mathrm{kg} / \mathrm{m} 2)$.

Obesity has become a global epidemic with an estimated 1.3 billion people overweight or obese. Its prevalence in developed countries, such as United States is high. National Health and Nutrition Examination Survey in United States indicated that an estimated 33.9 percent of US adults aged 20 and over are overweight, 35.1 percent obese and 6.4 percent are extremely obese ${ }^{[2]}$

"Globesity," a new term describing the global obesity epidemic, applies not only to adults but to children, who have been impacted by the poor eating habits and sedentary lifestyle of adults at an alarming rate-and are now facing diet-related health consequences from diabetes to cancers. Studies conducted by the World Health Organization (WHO) communicate two trends: an increase in the rise of global dietrelated non communicable diseases and an increase of the consumption of junk food. [3]
In response to the obesity epidemic, the First Lady, Michelle Obama, has made it a priority to combat this problem with a nationwide initiative called "Let's Move" which was launched on February 9th, 2010, and aims to prevent obesity in childhood. The ultimate goal is to focus on young children, so that in one generation, every child born after February 9th, 2010 will enter adulthood with a healthy weight. ${ }^{[4]}$

The industrialization, urbanization and the globalization increased incidence and prevalence of "non communicable" diseases which are considered today as "Life style diseases". The electronic gadgets, computers, internet and the mobile phones have made the individuals almost immobile. Recently there is an increasing prevalence of childhood obesity (5-19years) due to rapidly changing of dietary practices and a sedentary lifestyle in developing countries. Prevalence of childhood overweight and obesity worldwide has increased from $4.2 \%$ in 1990 to $6.7 \%$ in 2010 . The trend is anticipated to reach $9.1 \%$ in $2020^{[5]}$

Due to the basic aetiology of the condition, factors which are consistently highlighted in reviews of this subject are often those directly related to energy balance such as diet, physical activity and sedentary behaviour. $^{[6]}$ 


\section{MATERIAL \& METHODS:}

\section{Setting of Study:}

The study was conducted in the selected senior secondary schools of Jaipur, Rajasthan.

\section{Population:}

The population of the study comprised of students of senior secondary schools.

\section{Sample Size:}

Sample is a sub set of population, selected to participate in the study. Two hundred forty students who met the inclusion criteria were selected as the sample for the present study.

\section{Sampling Technique:-}

It is the purpose of selecting a portion of the population to represent the entire population. Purposive sampling is the selection of the most readily available persons as participants in a study who fulfill the purpose. Purposive sampling technique was used to select the samples for the study.

\section{DATA ANALYSIS AND INTERPRETATION:}

Part I: Percentage distribution of demographic variables of the students.

Table no 1: distribution of demographic variables of the students.

\begin{tabular}{|c|c|c|c|}
\hline S.NO. & VARIABLES & FREQUENCY & PERCENTAGE \\
\hline \multirow[t]{3}{*}{1} & AGE IN YEARS: & & \\
\hline & $14-16$ & 48 & $20 \%$ \\
\hline & $16-18$ & 192 & $80 \%$ \\
\hline \multirow[t]{3}{*}{2} & \multicolumn{3}{|l|}{ GENDER } \\
\hline & FEMALE & 208 & $86.67 \%$ \\
\hline & MALE & 32 & 13.33 \\
\hline \multirow[t]{3}{*}{3} & \multicolumn{3}{|l|}{ RELIGION } \\
\hline & HINDU & 236 & $98.33 \%$ \\
\hline & OTHERS & 4 & $1.67 \%$ \\
\hline \multirow[t]{4}{*}{4} & \multicolumn{3}{|c|}{ FACULTY OF EDUCATION } \\
\hline & SCIENCE & 132 & $55 \%$ \\
\hline & ARTS & 52 & $21.17 \%$ \\
\hline & COMMERECE & 56 & $23.33 \%$ \\
\hline \multirow[t]{3}{*}{5} & \multicolumn{3}{|c|}{ FOOD PATTERN OF FAMILY } \\
\hline & VEGETARIAN & 184 & $76.67 \%$ \\
\hline & MIXED & 56 & $23.33 \%$ \\
\hline \multirow[t]{5}{*}{6} & \multicolumn{3}{|l|}{ TYPES OF FAMILY } \\
\hline & NUCLEAR FAMILY & 136 & $56.67 \%$ \\
\hline & JOINT FAMILY & 88 & $36.67 \%$ \\
\hline & EXTENDD FAMILY & 8 & $3.33 \%$ \\
\hline & SINGLE FAMILY & 8 & $3.33 \%$ \\
\hline \multirow[t]{7}{*}{7} & \multicolumn{3}{|c|}{ INTERESTED IN EXTRA COCURRICULAR ACTIVITIES } \\
\hline & IF YES & 224 & $93.33 \%$ \\
\hline & SPORTS & 76 & $33.92 \%$ \\
\hline & MUSIC & 52 & $23.21 \%$ \\
\hline & DRAMA & 56 & $25 \%$ \\
\hline & DEBATE & 40 & $17.85 \%$ \\
\hline & IF NO & 16 & $6.67 \%$ \\
\hline \multirow[t]{7}{*}{8} & \multicolumn{3}{|c|}{ HAVING INFORMATION REGARDING PREVENTION OF OBESITY } \\
\hline & IF YES & 216 & $90 \%$ \\
\hline & T.V./MEDIA RADIO & 104 & $48.15 \%$ \\
\hline & TEACHER & 36 & $16.67 \%$ \\
\hline & $\begin{array}{l}\text { FRIENDS AND } \\
\text { RELATIVES }\end{array}$ & 12 & $5.56 \%$ \\
\hline & FAMILY & 64 & $29.63 \%$ \\
\hline & NO & 24 & $10 \%$ \\
\hline
\end{tabular}

Part B: Area wise analysis of knowledge score 
Table no. 2: Area wise mean, mean percentage and standard deviation of knowledge score

\begin{tabular}{|c|c|c|c|c|c|c|}
\hline s.n. & Area & $\begin{array}{l}\text { No. of } \\
\text { items }\end{array}$ & $\begin{array}{l}\text { Maximu } \\
\text { m score }\end{array}$ & $\begin{array}{l}\text { Me } \\
\text { an }\end{array}$ & Mean\% & SD \\
\hline 1 & $\begin{array}{l}\text { Knowledge } \\
\text { related to } \\
\text { obesity }\end{array}$ & 10 & 10 & $\begin{array}{l}4.63 \\
3\end{array}$ & 46.33 & $\begin{array}{l}2.70 \\
72\end{array}$ \\
\hline 2 & $\begin{array}{l}\text { Knowledge } \\
\text { related to } \\
\text { risk factor, } \\
\text { aetiology,p } \\
\text { athophysiol } \\
\text { ogy,complic } \\
\text { ation of } \\
\text { obesity }\end{array}$ & 10 & 10 & $\begin{array}{l}5.3 \\
5\end{array}$ & 53.5 & $\begin{array}{l}2.55 \\
3\end{array}$ \\
\hline 3 & $\begin{array}{l}\text { Knowledge } \\
\text { related to } \\
\text { diagnosis, } \\
\text { manageme } \\
\text { nt and } \\
\text { prevention } \\
\text { of obesity }\end{array}$ & 10 & 10 & $\begin{array}{l}4.48 \\
33\end{array}$ & $\begin{array}{l}44.8 \\
33\end{array}$ & $\begin{array}{l}3.13 \\
4\end{array}$ \\
\hline $\begin{array}{l}\text { Tot } \\
\text { al }\end{array}$ & Overall & 30 & 30 & $\begin{array}{l}14.4 \\
66\end{array}$ & $\begin{array}{l}48.2 \\
2\end{array}$ & $\begin{array}{l}8.39 \\
42\end{array}$ \\
\hline
\end{tabular}

The total mean percentage of knowledge scores of the 48.22 with total mean + SD of $14.466+8$ 8.3942. Area wise mean percentage of knowledge score was 46.33 in the area of introduction and BMI of obesity with mean +_SD of4.633+_2.7072. in the area of risk factors, aetiology, pathophysiology, Complication of obesity mean percentage was 53.5 with mean ${ }_{+}$SD of $5.35+2.553$. In the area of diagnosis, management, and prevention of obesity mean percentage was 44.833 with a mean +_SD of $4.4833+\_3.134$. This reveals that knowledge of students regarding habits in prevention of obesity was average in all the area.

CONCLUSION: The main aim of the study was to assess student with excellent knowledge. Teaching included introduction definition, risk factors, Diagnosis, complication, management and prevention of obesity. This helped the students to gain knowledge attitude practice regarding habits in prevention of obesity. The following conclusions were drawn on the basis of the findings of the study:

The knowledge scores among most of the students were poor and average.

$>$ The chances for the better practice in healthy habits in prevention of obesity could be anticipate.

$>$ The study paved the path to find a variety of other information regarding healthy habits in prevention of obesity RECOMMENDATION: Keeping in view the findings of the present study, the following recommendations have been made for further study:-

01. A similar study can be conducted on a larger sample, may help to draw more definite conclusions and make generalizations. 
02. The study may be replicated in different settings.

03. An experimental study could be undertaken with a control group

04. A follow- up study may be conducted to determine the effectiveness of the structured teaching programme

05. A comparative study can be conducted on school teacher of rural and urban schools and the findings can be compaired.

\section{REFERENCES:}

01. Gupta Piyush, Ghai O.P. textbook of preventive and social medicine second edition 2007 pg no, 456
02. Ogden et al. Prevalence of childhood and adult obesity inthe united state JAMA 2014;311(8):806814,doi;10.1001/jama.2014,732

03. Hawkes, the world wide battle against soft drinks in school 2002 DOI: http:// dx.doi.org/10.1016/I.amepre.2010.01 .011

04. ABC News, 2010 Michelle Obama:'Let's Move on childhood obesityabcnews.go.com $>$ GMA $>$ Heal th>story)

05. De Onis et al., obesity and public health-WHO Am J Clin Nutr 2010;92:1257-64

06. Swinburn etal,2011 Aug 27;378(9793):804-14 